\title{
Analisis Bidang Longsor Menggunakan Pendekatan Terpadu Geolistrik, Geoteknik Dan Geokomputer di Negeri Lima Ambon
}

\author{
Matheus Souisa*, Lilik Hendrajaya, Gunawan Handayani \\ Fisika Bumi dan Sistem Kompleks, Jurusan Fisika FMIPA ITB, \\ Jl. Ganesha no. 10 Bandung, Indonesia, 40132 \\ "Email: thos_sliding@yahoo.com
}

\begin{abstract}
Many methods have been used to assess landslide problems from a one-disciplinary, interdisciplinary and multidisciplinary approach. Several methods are being developed for integration in landslide investigations over the past decade, the focus of the study is directed towards a multidisciplinary investigative approach such as geo-electric surveys, geotechnical and geocomputation to determine landslide potentials to minimize landslide. The result of the study gives the slip plane located in the middle resistivity group with the type of sand or clay sand that overlies the high resistivity group in the form of hard bedrock. Based on the value of the slope safety factor, this slip area is in a less stable state. While the application of geocomputation indicates the location of the study is interpreted to be in a high hazard zone so that the potential for aftershocks will occur. From the results of the integrated study, the location of the study is still in unsafe condition and may occur after the landslide triggered by external factors. To minimize the aftershocks by lowering the groundwater face is to use the water toll model by utilizing small / large rivers under the slope / cliff to be able to flow water in the rainy season.
\end{abstract}

Keywords: Slip plane, geo-electric, geotechnical, geocomputation, water-tolls.

\section{ABSTRAK}

Telah digunakan banyak metode untuk mengkaji permasalahan longsor dari sudut pandangan pendekatan satu-disiplin, interdisiplin maupun multidisiplin. Beberapa metode sedang dikembangkan untuk dipadukan dalam investigasi longsor selama dekade terakhir ini, fokus studi diarahkan menggunakan pendekatan investigasi multidisiplin seperti survei geolistrik, geoteknik dan geokomputasi untuk menentukan potensi longsor sehingga dapat meminimalisir bencana longsor. Hasil kajian memberikan bidang gelincir terletak pada kelompok resistivitas menengah dengan jenis pasir atau pasir lempungan yang menindih kelompok resistivitas tinggi yang berupa batulempung keras (bedrock). Berdasarkan nilai faktor keamanan lereng, bidang gelincir ini berada pada keadaan kurang stabil. Sedangkan penerapan geokomputasi menunjukkan lokasi kajian ditafsirkan berada dalam zona bahaya yang tinggi sehingga sangat berpotensi adanya longsor susulan. Dari hasil kajian terpadu, lokasi kajian masih dalam kondisi tidak aman dan bisa terjadi longsor susulan jika dipicu oleh faktor luar. Untuk meminimalisir longsor susulan dengan menurunkan muka air tanah adalah menggunakan model tol air dengan memanfaatkan sungai-sungai kecil/besar yang terdapat di bawah lereng/tebing untuk dapat dialirkan air pada musim hujan.

Kata kunci: Bidang longsor, geolistrik, geoteknik, geokomputasi, tol air. 


\section{PENDAHULUAN}

Longsor (landslide) sebetulnya merupakan fenomena alam yang kompleks dalam mencari keseimbangan baru ${ }^{[1,2]}$ akibat adanya gangguan atau faktor yang mempengaruhi dan menyebabkan terjadinya pengurangan kuat geser serta peningkatan tegangan geser tanah. Longsor sering terjadi di daerah perbukitan dan pegunungan ${ }^{[3]}$. Hal inilah yang menyebabkan kerusakan infrastruktur dan lingkungan, korban jiwa dan kerugian harta benda yang cukup besar ${ }^{[4,5]}$, dan memberikan kontribusi yang signifikan terhadap evolusi bentuk lahan ${ }^{[6,7]}$. Indonesia merupakan negara keempat di dunia yang sering terjadi tanah longsor dan korban jiwa ${ }^{[8]}$. Menurut Bachri dan Sheresta ${ }^{[9]}$, bencana longsor di Indonesia dipengaruhi oleh kondisi iklim tropis dengan curah hujan yang tinggi dari tahun ke tahun ${ }^{[10]}$. Hal ini sangat berdampak pada wilayah Pulau Ambon merupakan daerah yang rentan terhadap bahaya longsor dengan intensitas bencana longsor dan banjir diperkirakan meningkat dari tahun ke tahun lebih dari $60 \%$ $[11,12]$.

Investigasi longsor berkembang pesat dari tahun ke tahun seiring dengan intesitas longsor dengan menerapkan berbagai metode kajian. Terdapat beberapa metode dalam mengkaji permasalahan longsor seperti metode geofisika untuk mengidentifikasi bidang gelincir, metode geoteknik untuk memprediksi kestabilan lereng, metode geokomputasi (citra satelit dan overlay) untuk interprestasi kerawanan longsor, metode geokimia untuk mengidentifikasi kandungan unsur lempung, dan lain sebagainya. Investigasi longsor menggunakan kombinasi data dari interpretasi geolisrik dan geoteknik telah dilakukan oleh Luna dan Jadi ${ }^{[13]}$, Dobrescu ${ }^{[14]}$, Abidin ${ }^{[15]}$, Akinrinmade ${ }^{[16]}$. Kemudian kombinasi data geokomputasi dan geoteknik sudah dilakukan oleh Grandjean ${ }^{\text {[17], }}$ Soralumb ${ }^{[18]}$, Anwar ${ }^{[19]}$. Namun, belum dilakukan kombinasi data dari metode yang diusulkan sehingga layak untuk studi lebih lanjut, karena keakuratan suatu interpretasi tergantung pada hasil kajian secara terpadu baik dari segi kualitatif maupun kuantitatifnya. Beberapa penelitian sudah dikemukakan dan sedang dikembangkan metode dalam kaitannya tentang investigasi terjadinya longsor selama dekade terakhir ini, fokus studi diarahkan menggunakan kombinasi metode geolistrik, geoteknik dan geokomputasi untuk meminimalisir bahaya/resiko longsor Negeri Lima Ambon.

\section{METODE}

Survei pengambilan data geolistrik dan geoteknik dilakukan di perbukitan Ulakhatu Desa Negeri Lima Kec.Laihitu Ambon, yang secara geografis terletak pada koordinat

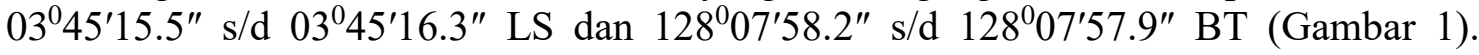
Longsor Negeri Lima terjadi pada 13 Juni 2012 membentuk dam alam Wae Ela dan pada tanggal 25 Juli 2013 dam alam ini jebol ${ }^{[11,20]}$. Penelitian untuk mengkaji longsor di lokasi studi dilakukan sejak tahun 2012 dan selalu monitoring sampai tahun 2017 ini. Pada umumnya, tatanan stratigrafi lokasi kajian tersusun atas jenis dan distribusi batuan antara lain batuan gunungapi berupa batuan gunungapi Ambon merupakan jenis yang paling dominan, batuan permukaan berupa batuan alluvium, dan batuan beku berupa batuan granit Ambon. Dari segi tatanan fisiografi, dimana morfologi tersusun atas satuan perbukitan dataran rendah sampai perbukitan bergelombang kasar dengan kemiringan berkisar antara $15^{0}-30^{\circ}$ ) sekitar $73 \%$ dengan elevasi mencapai 600 mdpl [21]. 


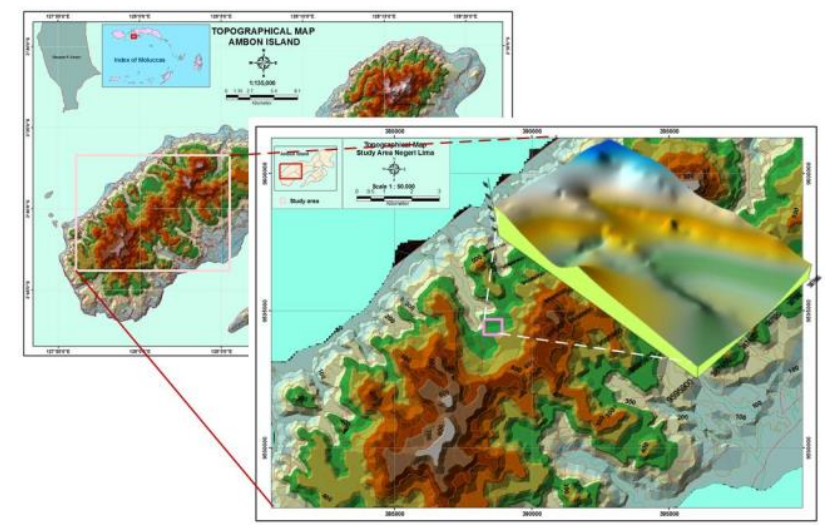

Gambar 1. (color online) Peta lokasi penelitian

Salah satu faktor pemicu terjadinya longsor di wilayah penyelidikan akibat kegagalan lereng adalah bidang gelincir, dimana material tanah/batuan akan bergerak di atas bidang tersebut mengalir mengumpul menuruni lereng dengan kecepatan tinggi ${ }^{[20]}$. Untuk menentukan bidang kontak digunakan metoda geolistrik resistivitas. Nilai resistivitas terukur merupakan resistivitas semu $\rho_{a}=K(\Delta V / I)$ bergantung pada spasi elektroda ${ }^{[22]}$, dengan $\rho_{\mathrm{a}}$ adalah resistivitas semu ( $\left.\Omega . \mathrm{m}\right), \Delta \mathrm{V}$ adalah beda potensial (volt), I adalah kuat arus (A) dan $K=\pi n(n+1) a$ adalah faktor geometri (m) untuk konfigurasi WennerSchlumberger ${ }^{[23,24]}$, a $(\mathrm{m})$ adalah jarak antara kedua elektroda arus sama dengan jarak antara kedua elektroda potensial dan $\mathrm{n}=1,2,3,4, \ldots \ldots$. Akuisisi data lapangan dilakukan setelah lintasan dan titik pengamatan ditentukan di daerah penelitian untuk pengambilan data lapangan. Pengambilan data resistivitas lapangan dengan konfigurasi WennerSchlumberger menggunakan peralatan Resistivitymeter. Hasil pengukuran yang diperoleh dianalisis untuk menghasilkan penampang 2D model bawah permukaan. Kemudian untuk mengetahui sebaran nilai resistivitas sebenarnya pada area survei dilakukan dengan model stratigrafi tipe fence model. Model stratigrafi tersebut merupakan model yang menggabungkan lima true resistivitas menjadi satu bagian sehingga distribusi spasial material dapat teramati secara 3-D. Titik perpotongan empat bidang dalam fence model tersebut merupakan titik perpotongan dari lintasan electrical sounding.

Penerapan metode geoteknik dalam penelitian ini hanya untuk menyelidiki pengujian sifat fisik tanah dengan pengumpulan sampel yang mewakilan terganggu dengan menggunakan boring dengan tujuan untuk menguji kestabilan lereng. Setelah menentukan titik boring bersamaan dengan lintasan geolistrik dilakukan pengeboran dengan kedalaman tertentu. Selanjutnya sampel tanah di uji laboratorium untuk menentukan sifat tanah (seperti angka pori, porositas, derajat kejenuhan, kadar air, berat jenis tanah, berat isi air, berat isi butir, berat isi tanah, berat volume kering, berat isi celup tanah) dan batas-batas konsistensi (Atterberg limits) serta tegangan geser dan normal. Evaluasi stabilitas lereng dilakukan pada dua kondisi, yaitu kondisi lereng sebelum terjadinya longsor dan kondisi lereng pasca-longsor dengan pendekatan metode elemen hingga (FEM). Geometri lereng untuk kedua kondisi ini di desain ulang berdasarkan geometri longsor di lapangan. Untuk memudahkan usaha trial and error terhadap stabilitas lereng maka titik-titik pusat bidang longsor yang berupa busur lingkaran harus ditentukan dahulu melalui suatu perhitungan numerik. Permukaan slip potensial untuk lereng adalah dua dimensi dan merupakan bagian lingkaran. Evaluasi lereng dilakukan dengan FEM menggunakan software Plaxis [25]. Dengan memanfaatkan FEM, tidak digunakan asumsi bidang longsor. 
Faktor kramanan $\left(\mathrm{F}_{\mathrm{S}}\right)$ lereng diperoleh dengan mencari bidang lemah pada struktur lapisan tanah/batuan. FS diperoleh dengan cara mengurangi nilai kohesi dan sudut geser dalam tanah secara bertahap, hingga lapisan tanah/batuan mengalami longsor.

Pemetaan lapangan dilakukan untuk pengambilan titik acuan termasuk didalamnya pengambilan sampel untuk mendapatkan data-data tentang faktor-faktor yang berpengaruh terhadap terjadinya longsor. Parameter yang digunakan untuk pengamatan di lapangan antara lain curah hujan, kelerengan, struktur geologi, tata guna lahan, jenis tanah, gempa dan patahan/sesar. Parameter-parameter ini kemudian diberi bobot sesuai dengan besar kecilnya pengaruh parameter tersebut terhadap terjadinya longsor yang merujuk pada Kementerian Pekerjaan Umum ${ }^{[26]}$. Penilaian tingkat bahaya longsor terhadap aspek fisik alami dilakukan melalui penjumlahan nilai bobot dari tujuh indikator pada aspek fisik alami. Kemudian dilakukan metode kuantitatif analisis spasial yaitu memanfaatkan teknologi Sitem Informasi Geografis (SIG), dengan pendekatan model pendugaan zonasi bahaya longsor ${ }^{[27,28]}$. Setelah dihasilkan data spasial baru, dilakukan klasifikasi data atas kriteria tertentu terhadap data yang diteliti dengan memberikan nilai skor dibagi ke dalam tiga zona tingkat kerentanan terhadap bahaya longsor pada wilayah bahaya longsor ${ }^{[29]}$. Peta sebaran bahaya longsor dijadikan sebagai acuan pemetaan risiko bahaya longsor. Nilai risiko longsor dihasilkan dari penjumlahan nilai bahaya dan skor dari kepadatan (peruntukan ruang pemukiman).

\section{HASIL DAN PEMBAHASAN}

\section{Pemodelan penampang 2-D resistivitas batuan}

Setelah dilakukan pengukuran dengan GPS pada setiap jarak pengukuran untuk menentukan peta kontur bidang gelincir dan lintasan pengukuran, diperoleh ketinggian daerah longsor antara 145 m.dpl - 220 m.dpl dan memiliki lereng yang berbeda. Lintasan pengukuran lokasi Negeri Lima terdiri dari 5 (lima) lintasan membentang dari utara - selatan dengan panjang lintasan $200 \mathrm{~m}$ dan jarak antar tiap lintasan $25 \mathrm{~m}$.

Model stratigrafi yang dibuat pada Line LN-1 hingga LN-5 adalah model stratigrafi tipe fence model. Penggabungan lima bidang yang merupakan potongan dari runtuhan bukit Ulakhatu memudahkan pengamatan material penyusun dari segala arah. Model stratigrafi tipe fence model dari lintasan electrical sounding disajikan pada (Gambar 2). Pada fence model material penyusun lokasi kajian, lempung maupun lanau dan pasiran dipisahkan menjadi dua lapisan. Gambar 2, didominasi oleh nilai resistivitas yang rendah hingga sedang dengan kenampakan sebaran resistivitas pada Line LN-1 berbeda dengan Line LN-2 hingga Line LN-5 dimungkinkan terjadi pada kedalaman 2-5 m. Sedangkan pada kedalaman lebih dari $5 \mathrm{~m}$, kenampakan sebaran resistivitas Line LN-1 menyerupai dengan Line LN-2 hingga Line LN-5. Hal ini terdapat kemungkinan penyebaran zona gelincir longsor disekitar $x=8-58 \mathrm{~m}$ dan $x=136-160 \mathrm{~m}$ pada Line LN-1 menerus hingga Line LN-4. Anomali resistivitas sebaran longsor pada arah vertikal mencapai kedalaman $15 \mathrm{~m}$. Alterasi anomali ini memungkinkan potensi sebaran longsor tetap pada lokasi semula apabila terjadi gangguan-gangguan pada lereng tersebut dan berpeluang bergeser ke arah timur laut dengan prediksi kecepatan longsor berkurang dari sebelumnya. Sedangkan pada arah horizontal sebaran longsor mengikuti arah kemiringan potensi longsor searah dengan bidang gelincir yaitu mengarah ke barat daya, hal ini didukung oleh kondisi topografi yang semakin curam. 


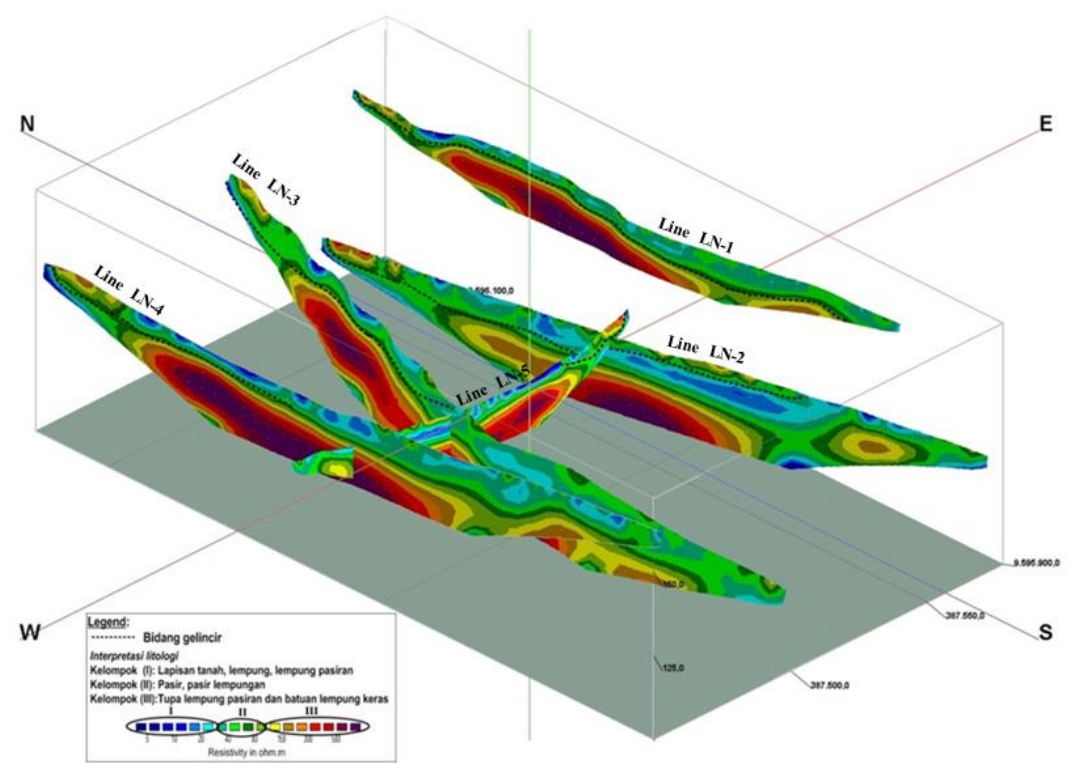

Gambar 2. (color online) Profil penampang 3-D resistivitas pada lintasan NL-01 - 05

Interpretasi secara umum dari tiap datum point pada penampang resistivitas menunjukkan nilai resistivitas antara 5 - $500 \mathrm{ohm} . \mathrm{m}$ (Gambar 2) pada posisi bagian atas tebing dengan rincian sebagai berikut:

Kelompok resistivitas pertama dengan nilai resistivitas rendah $(<40$ ohm.m) diduga sebagai tanah, lempung dan lempung pasiran, umumnya bersifat lepas dan lembab.

Kelompok resistivitas kedua dengan nilai resistivitas menengah (40 - 80 ohm.m) diduga sebagai pasir, pasir lempungan berbutir halus hingga kasar, lempungan dan kerikilan.

Kelompok resistivitas ketiga dengan nilai resistivitas tinggi (> $80 \mathrm{ohm} . \mathrm{m}$ ) diduga sebagai batu lempung pasiran berbutir halus hingga sedang dan batulempung yang kompak. Pada beberapa titik lokasi ditemukan adanya retakan-retakan memanjang. Kolompok batuan ini umumnya bertindak sebagai batuan dasar (bedrock) hampir di seluruh daerah survei.

Hasil analisis menunjukkan bahwa lokasi bidang gelincir yang merupakan bidang rawan longsor terletak pada kelompok resistivitas menengah dengan jenis pasir atau pasir lempungan yang menindih kelompok resistivitas tinggi yang berupa bedrock. Gambar 2, merupakan indikasi persebaran zona lempung yang menunjukkan bahwa zona lempung tersebar di seluruh daerah penelitian. Zona bagian paling bawah dari penampang tersusun atas bongkahan atau blok dari batuan lempung merupakan lapisan kedap air (impermeable) dan lebih mudah menggelincirkan material massif diatasnya. Zona bagian di atas blok dari batuan lempung tersusun dari akumulasi lapisan lempung yang bercampur dengan batuan lapuk yang tidak kedap air (permeable) berupa lapisan pasir dan pasir lempung. Kedua lapisan ini saling kontak dan membentuk kemiringan terhadap permukaan tanah. Hal ini nampak dari kontras resistivitas antar dua batuan yang saling berdekatan

\section{Hasil uji laboratorium dan evaluasi stabilitas lereng}

Uji indeks dilakukan untuk mengidentifikasi dan menentukan karakteristik material. Selain itu, tujuannya adalah juga untuk mengklasifikasikan tanah berdasarkan distribusi ukuran butirannya. Sampel tanah yang digunakan untuk semua pengujian dalam penelitian ini adalah tanah di lokasi bekas longsor, dan sampel tanah diambil saat musim kemarau sebanyak dua sampel uji. Hasil pengujian sifat fisik tanah/batuan menunjukkan bahwa 
tanah dikategori lempung dengan prosentasi fraksi lempung $0.002 \mathrm{~mm}(2 \mu \mathrm{m})$, berkisar antara $25.55-42.98 \%$ dan kadar air tanah berkisar antara $9.21-30.56 \%$. Hasil uji indeks properti (index properties test) ditampilkan pada Gambar 3 dan 4, dan ditabulasikan pada Tabel 1. Berdasarkan Tabel 1, menunjukkan bahwa tanah lokasi penelitian mempunyai karakteristik tanah lempung ekspansif dengan kisaran nilai Gs mengandung mineral lempung lanau anorganik, pasir dan kerikil. Tanah pada lokasi longsor Negeri Lima diklasifikasikan berada dalam kelompok campuran batupasir dan lanau. Parameter indeks ukuran butiran menunjukkan bahwa di lokasi penelitian dijumpai tanah padat hasil peninggalan longsor. Karena tanah permukaan atau yang tidak padat telah terkikis dan terbawa oleh longsor.

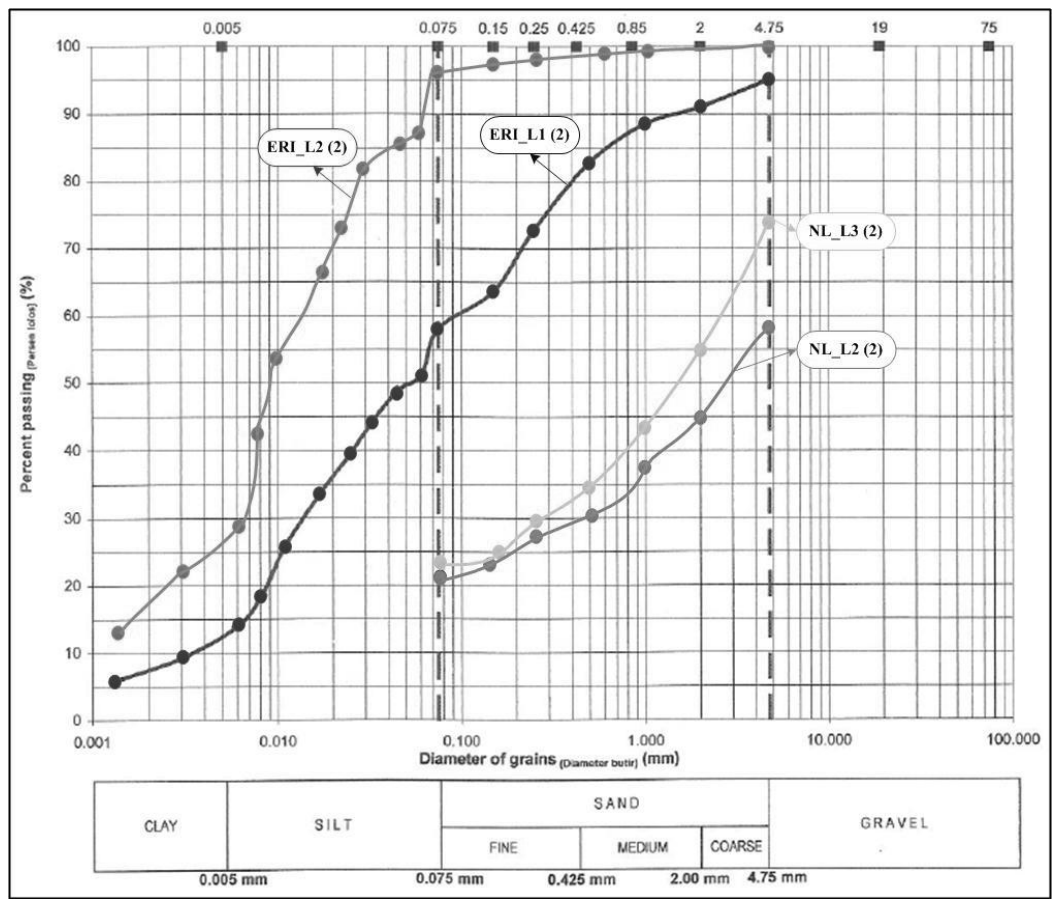

Gambar 3. Kurva distribusi ukuran butir tanah/batuan Negeri Lima

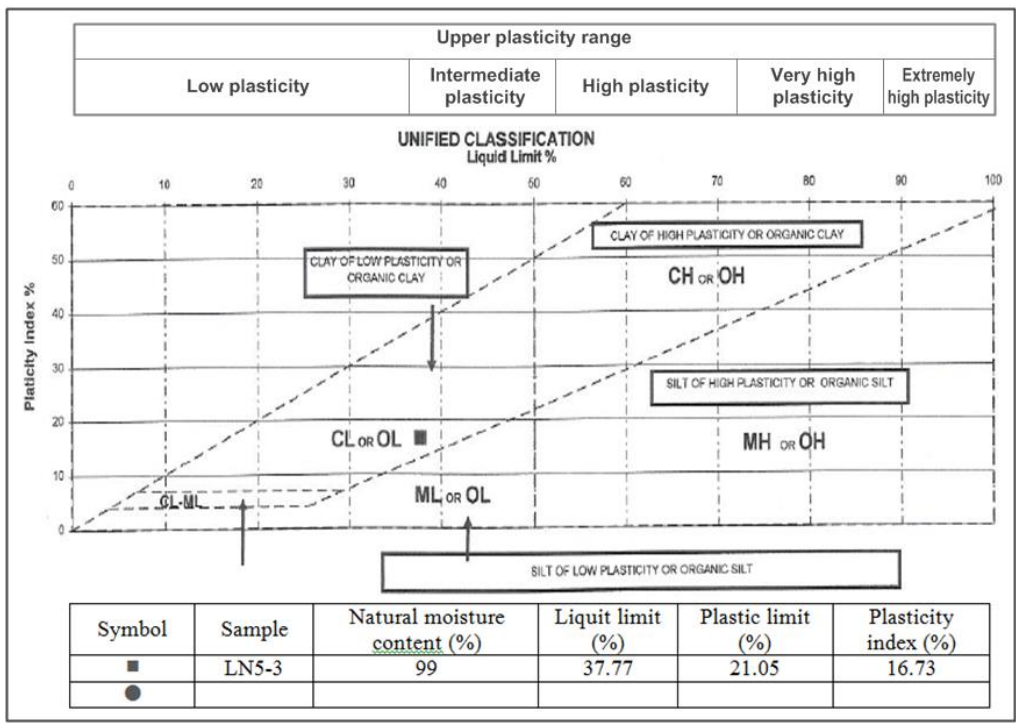

Gambar 4. Kurva Atterberg limit untuk sample LN5-3

Tabel 1. Hasil uji indeks properti tanah Lokasi Negeri Lima 


\begin{tabular}{lcc}
\hline Sampel No & $\mathrm{L}-2$ & $\mathrm{~L}-3$ \\
\hline Depth, $(\mathrm{m})$ & 2 & 2 \\
Water content $\mathrm{w},(\%)$ & 23.76 & 16.95 \\
Spesific gravity Gs & 2.69 & 2.63 \\
Wet density $\gamma_{\mathrm{w}},\left(\mathrm{t} / \mathrm{m}^{3}\right)$ & 1.86 & 1.67 \\
Dry density, $\gamma_{\mathrm{d}},\left(\mathrm{t} / \mathrm{m}^{3}\right)$ & 1.50 & 1.43 \\
Void ratio $(\mathrm{e})$ & 0.79 & 0.84 \\
Porosity $(\mathrm{n})$ & 0.44 & 0.46 \\
Saturated deg. $(\%)$ & 80.91 & 53.04 \\
Liquit limit, $(\%)$ & 34.52 & 41.24 \\
Plastic limit, $(\%)$ & 18.82 & 21.89 \\
Plastisity index, $(\%)$ & 15.70 & 19.35 \\
Poisson ratio, $v$ & 0.25 & 0.25 \\
Kohesion, $c\left(\mathrm{kN} / \mathrm{m}^{2}\right)$ & 10.9 & 12.2 \\
Sudut gesek dalam, $\phi\left({ }^{\circ}\right)$ & 35.7 & 37.3 \\
\hline
\end{tabular}

Evaluasi stabilitas lereng dilakukan untuk mengetahui mekanisme longsor dengan menggunakan geometri lereng dari hasil pengukuran topografi. Dengan pengambilan sampel tanah yang dilakukan hanya pada kedalaman dangkal mencapai $3 \mathrm{~m}$, kerena lerengnya terjal dan sempit sangat sulit untuk memobilisasi dan menempatkan peralatan sondir, sehingga menggunakan hand bor. Dengan hand bor, ada titik bor yang bisa mencapai kedalaman $3 \mathrm{~m}$, namun ada juga yang tidak bisa mencapai kedalaman tersebut. Hal ini disebabkan lapisan tanah yang padat dan keras serta berbatuan. Untuk mendapatkan hasil yang diinginkan, dilakukan desain ulang geometri lereng sesuai di lapangan. Gambar ini untuk menginput data geometri ke dalam program Plaxis, digunakan data alternatif kelompok pengujian tanah-batuan berdasarkan kombinasi prediksi parameter tanah sesuai hasil laboratorium, interpretasi geolistrik resistivitas (kedalaman bidang gelincir) dan referensi yang terkait melalui pendekatan trial and error method untuk mendapatkan hasil yang diinginkan sesuai di lapangan. Kajian data-data ini digunakan untuk memprediksi kelompok tanah-batuan seperti berat jenis tanah, kohesi dan sudut geser guna memodelkan kelongsor lereng sesuai kenyataan di lapangan. Kajian kasus lereng dievaluasi dengan FEM menggunakan software Plaxis untuk mengevaluasi kondisi stabilitas dan mengevaluasi berbagai kombinasi beban dan (atau) kondisi alam yang dapat mempengaruhi stabilitas lereng di massa yang akan datang. Penelitian ini berfokus pada pengaruh variasi groundwater table (GWT) di musim kering dan basah.

Geometri lereng sebelum terjadi longsor di desain ulang berdasarkan geometri longsor di lapangan. Data hasil kajian topografi geometri sebelum terjadi longsor diinputkan kedalam solusi numerik dengan FEM (software Plaxis) untuk mengevaluasi kondisi stabilitas lereng sebelum longsor berdasarkan faktor kemanana lereng $\left(F_{\mathrm{S}}\right)$. Hasil analisis $F_{\mathrm{S}}$ berdasarkan solusi FEM disajikan pada Gambar 5. Bidang longsor dari hasil analisa dengan Plaxis menunjukkan saat tidak hujan GWT jauh dari permukaan bidang tanah, $F_{\mathrm{S}}=1.10\left(F_{\mathrm{S}}>\right.$ 1.0) tetapi nilai ini mengindikasikan bahwa kondisi tanah yang ada sudah kritis. Masalah kestabilan lereng pada lokasi kajian setelah terjadinya longsor diselidiki kembali. Hal ini disebabkan lereng terjadi pengikisan oleh air hujan dan lereng bawah mengalami perubahan oleh aliran air sungai. Hasil analisis $F_{\mathrm{S}}$ (Gambar 6 ), mengindikasikan adanya aliran air cenderung meningkat terdapat pada kaki lereng. Hal ini terkonfirmasi dengan adanya mata air di kaki lereng pasca longsor. Pengaruh aliran air tanah sangat signifikan 
pada proses kelongsor lereng pada empat lokasi penelitian. Hasil simulasi menunjukaan bahwa peninggian muka air tanah pada lereng dapat menurunkan $F_{\mathrm{S}}=0.89\left(F_{\mathrm{S}}<1.0\right)$.

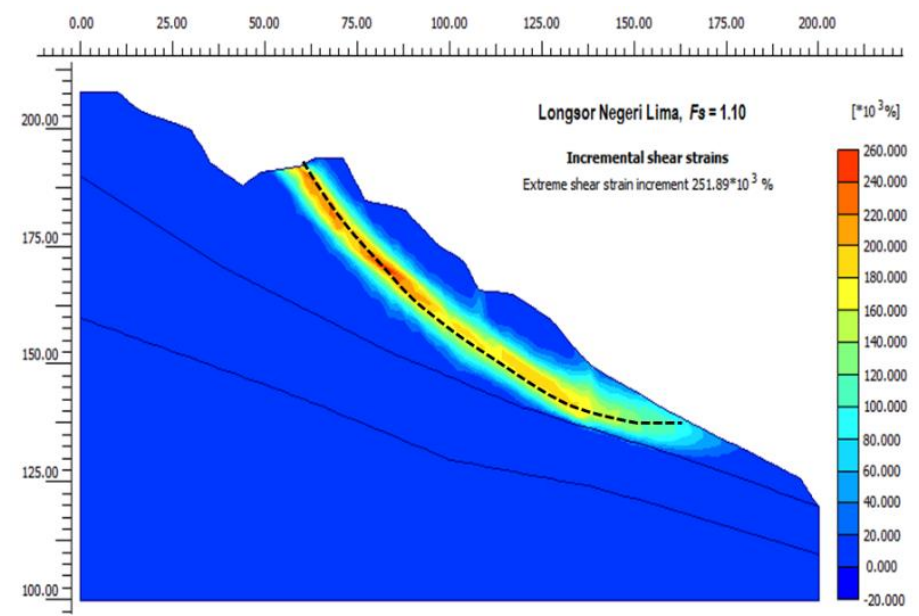

Gambar 5. (color online) Bidang gelincir pada lereng dengan muka air tanah normal

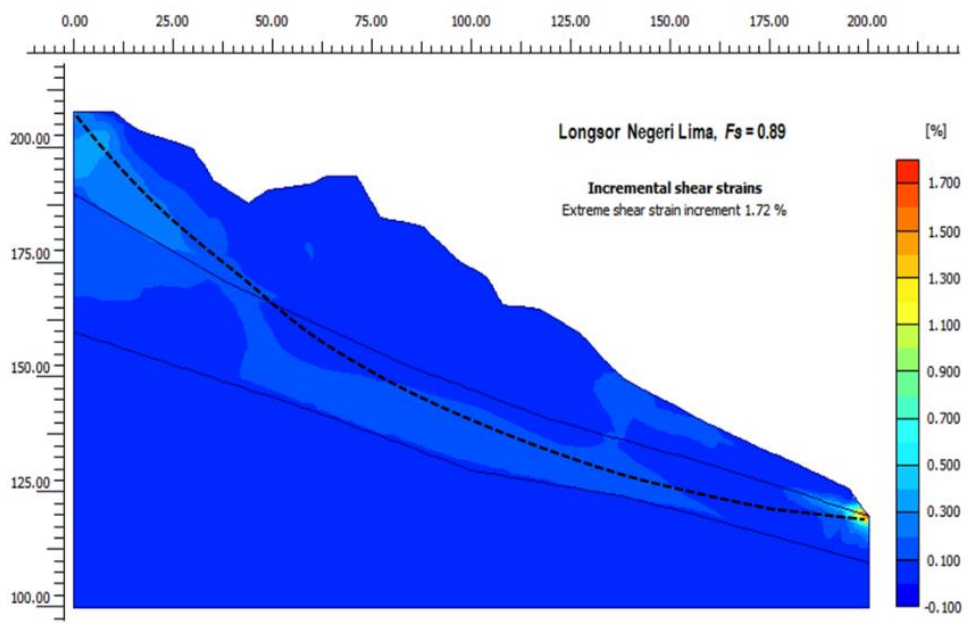

Gambar 6. (color online) Bidang gelincir pada lereng dengan muka air tanah meningkat

Hasil simulasi FEM, potensi bidang gelincir berada pada lereng atas. Potensi bidang gelincir menandakan tipe longsor adalah rotational slide. Sedangkan dari pendataan geolistrik, diduga bahwa bidang gelincir berada pada bidang pertemuan lempung berpasir-kerikil (breccia vulkanik) dengan lempung keras (tuff impermeable). Dengan memperhatikan $F_{\mathrm{S}}$ mendekati nilai 1, ketika muka air tanah naik dengan anggapan terjadi hujan yang mengakibatkan kondisi tanah menjadi semakin jenuh dengan $F_{\mathrm{S}}<1$ (Gambar 6) dimungkinkan dapat mengakibatkan terjadi longsor susulan apabila dipicu oleh gaya luar. Terlihat juga bahwa tanah yang cenderung longsor adalah tanah pada lapisan 1 (dengan bidang longsor antara lapisan 1 dan lapisan 2) yaitu lapisan tanah yang mengalami pelapukan (tanah residual), sedang lapisan 2 sedikit terdeformasi dan lapisan 3 tidak terdeformasi. Keberadaan air dalam lapisan tanah memang sangat berpengaruh pada kekuatan tanah, besarnya tekanan pori dapat memperbesar deformasi yang terjadi pada saat menerima beban, bila dibandingkan dengan kondisi kering tanpa air tanah. Keberadaan tekanan pori akan mereduksi beberapa parameter kekuatan efektif dari tanah seperti sudut gesek internal, kohesi dan modulus deformasi dari tanah. Pada hasil ini keberadaan air tanah memberikan pengaruh maksimum pada sisi lereng bagian bawah. 
Untuk mengetahui bahwa hasil analisis telah benar dilakukan validasi yaitu dengan membandingkan jarak antara rekahan tarik pada permukaan crest lereng dan hasil perhitungan dengan kenyataan di lapangan. Berdasarkan hasil pengamatan bahwa rekahan tarik rata-rata berada sekitar $10.5 \mathrm{~m}$ dari tepi lereng, sementara hasil perhitungan jarak rata-rata $11.5 \mathrm{~m}$ yang terjadi pasca longsor. Hal ini tidak jauh berbeda antara hasil pengamatan lapangan dan hasil perhitungan dengan perbedaan sebesar $8.7 \%$, dapat dinyatakan valid. Berarti model longsor yang mendekati kondisi lapangan. Dengan demikian, daerah penelitian diduga dalam keadaan kritis dan berpotensi untuk terjadinya longsor susulan jika dipicu oleh faktor alam dan non-alam yang menyertainya. Hal ini terbukti dibuktikan dengan adanya beberapa kali longsor susulan dalam skala yang kecil di lokasi kajian sejak tahun 2014 sampai tahun 2017 ini.

\section{Interpretasi bahaya longsor menggunakan aplikasi SIG}

Untuk mengukur zona bahaya (hazard zone) longsor dapat ditentukan berdasarkan tujuh parameter fisik alami yang terdiri dari kemiringan lereng, kondisi tanah, batuan penyusun lereng, curah hujan, tataguna lahan, kegempaan dan patahan/sesar/gawir. Parameterparameter ini kemudian diberi bobot sesuai dengan besar kecilnya pengaruh parameter tersebut terhadap terjadinya longsor. Setelah dihasilkan data spasial baru, dilakukan klasifikasi data atas kriteria tertentu terhadap data yang diteliti dengan memberikan nilai skor dibagi ke dalam 3 kelas, selanjutnya di jumlahkan dan dengan membagi selisih nilai tersebut dengan tiga kelas (zona) tingkat kerentanan terhadap bahaya longsor pada wilayah kerentanan longsor. Setelah menetapkan nilai sebaran bahaya longsor, maka indeks zona bahaya longsor dihitung untuk semua parameter dalam setiap sel. Menggunakan jumlah zona bahaya longsor untuk setiap sel, disiapkan peta sebaran bahaya longsor (Gambar 7) untuk wilayah studi.

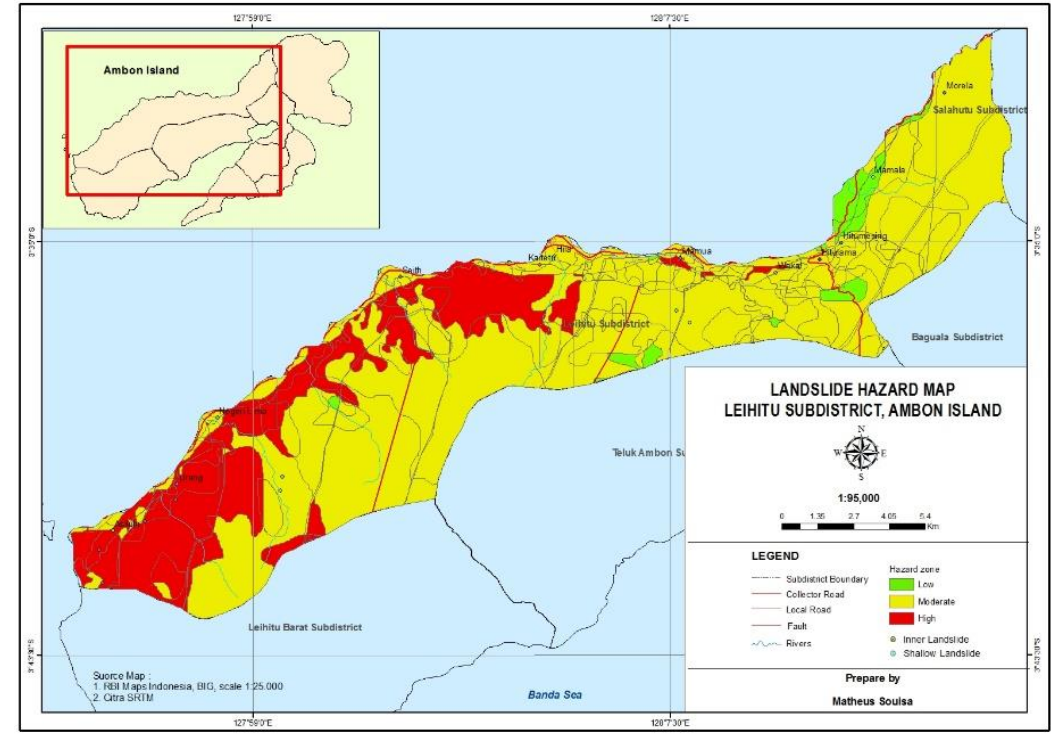

Gambar 7. (color online) Peta zona bahaya longsor Kecamatan Leihitu

Berdasarkan nilai kumulatif sebaran bahaya longsor, diklasifikasikan daerah menjadi 3 zona ketidakstabilan relatif. Berikut hasil rekapitulasi nilai bahaya tanah longsor pada zona yang berbeda disajikan pada Tabel 2. Hasil dari penilaian dan klasifikasi tingkat bahaya longsor yang dominan di daerah penelitian disebarkan atas sel-sel desa dan dihitung berdasarkan total luas wilayah Kecamatan Leihitu yaitu tingkat kapasitas rendah atau stabil (3.92 \%), tingkat kapasitas sedang atau tidak stabil (65.07\%) dan tingkat kapasitas tinggi $(31.07 \%)$. 
Table 2. Nilai zona bahaya longsor

\begin{tabular}{clcr}
\hline Indeks Bahaya Longsor & Zona Bahaya & Luas, $\left(\mathrm{km}^{2}\right)$ & Luas (\%) \\
\hline $3.69-4.75$ & Tinggi & 46.05 & 31.07 \\
$2.63-3.68$ & Sedang & 96.62 & 65.07 \\
$1.55-2.62$ & Rendah & 5.82 & 3.92 \\
\hline Total & & 148.49 & 100.00 \\
\hline
\end{tabular}

Peta sebaran bahaya longsor yang telah diajukan dan dijadikan sebagai acuan pemetaan risiko bahaya longsor pada ruang pemukiman. Pengkajian peta risiko bahaya longsor dapat berlaku sampai dengan 5 tahun kedepan. Dinamika Kecamatan Leihitu dengan jumlah penduduk setiap tahun bertambah, sudah tentu membawa dampak pemenuhan sarana prasarana dasar dan jenis aktivitas baru lainnya. Salah satu kebutuhan ruang yang paling mendasar yaitu permukiman. Untuk memenuhi kebutuhan tersebut, pemerintah kabupaten/kecamatan melakukan perencanaan tata ruang sesuai kawasan permukiman. Dimana kawasan permukiman ini termasuk dalam kawasan permukiman pedesaan dengan kegiatan utama pertanian termasuk pengelolaan sumberdaya alam, pelayanan jasa pemerintahan, pelayanan sosial dan kegiatan ekonomi. Hasil analisis overlay antara peta kawasan pemukiman dengan peta sebaran bahaya longsor seperti disajikan pada Gambar 8 dan Tabel 3, menunjukkan bahwa beberapa kawasan yang diperuntukkan sebagai kawasan permukiman berada pada daerah dengan risiko longsor tinggi dan berpotensi longsor.

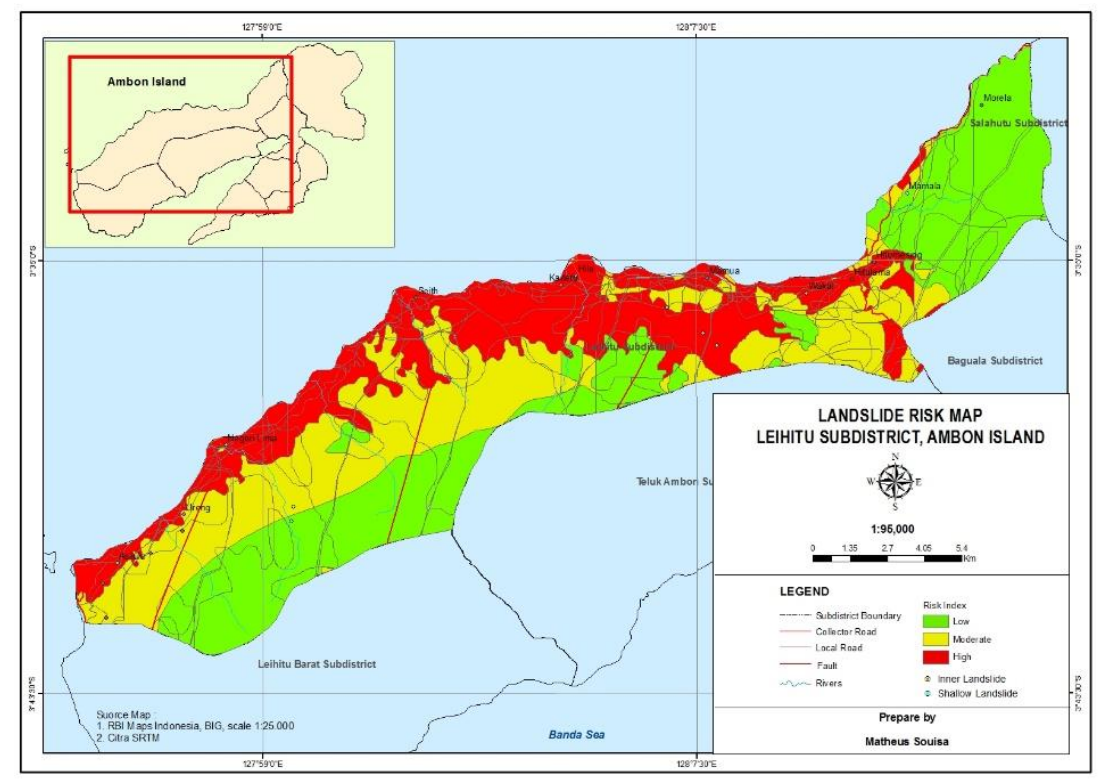

Gambar 8. (color online) Peta risiko longsor Kecamatan Leihitu

Wilayah Kecamatan Leihitu khususnya Desa Negeri Lima bertopografi datar hingga terjal namun memiliki tingkat kerentanan tinggi. Hal ini salah satunya disebabkan oleh susunan tanahnya berupa lapukan Formasi gunungapi Ambon anggota batuan vulkanik. Batuan vulkanik dikenal memiliki potensi kembang kerut tinggi - sangat tinggi. Daerah Negeri Lima memiliki curah hujan tinggi lebih dari $200 \mathrm{~mm} /$ hari ${ }^{[20]}$, merupakan daerah yang cenderung basah. Perubahan siklus hujan-kering dapat menyebabkan material vulkanik mengalami perubahan sifat, dimana saat kadar air tinggi vulkanik akan 
mengembang dan saat kadar air berkurang mengerut. Perubahan ini menyebabkan bertambahnya kuat geser tanah dan menyebabkan longsor luncuran ( fall) yang bersifat cepat. Penentuan tingkat kerentanan longsor menggunakan metode informasi dapat mengidentifikasi dengan baik lokasi rentan longsor tipe luncuran (fall), aliran (flow) dan nendatan (slides) yang melibatkan kondisi topografi agak curam hingga curam, kondisi batuan lapuk, tata guna lahan terbuka dan kondisi basah bercurah hujan tinggi.

Tabel 3. Rekapitulasi data atribut risiko longsor Kecamatan Leihitu

\begin{tabular}{clcr}
\hline Indeks Risiko Longsor & Zona Risiko & Luas, $\left(\mathrm{km}^{2}\right)$ & Luas (\%) \\
\hline $14.88-19.10$ & Tinggi & 45.32 & 30.52 \\
$10.64-14.87$ & Sedang & 49.33 & 33.22 \\
$6.40-10.63$ & Rendah & 53.84 & 36.26 \\
\hline Total & & 148.49 & 100.00 \\
\hline
\end{tabular}

\section{Korelasi terpadu}

Sulit untuk membedakan dengan hanya survei geolistrik untuk memutuskan apakah lereng memiliki kondisi normal atau kritis, karena zona resistivitas rendah selalu menjadi zona yang bermasalah. Akibatnya kajian menyangkut bidang gelincir dan stabilitas lereng dilakukan dengan mengkombinasi hasil interpretasi analisis data dengan pendekatan geolistrik dan geokomputasi, dan diperlukan adanya data geoteknik berupa data bor. Data geoteknik digunakan sebagai data pengikat dari hasil pengolahan data lapangan yang berupa nilai tahanan jenis setiap lapisan batuan dan tingkat kerawanan bahaya longsor. Analisis uji laboratorium (geoteknik) diinterpretasi terdiri dari lempung dan lanau berpasir. Berdasarkan analisis ini tidak terdapat perbedaan jenis tanah di bawah permukaan pada daerah penelitian berupa nilai tahanan jenis lapisan batuan dan data bor. Sedangkan korelasi antara hasil interprestasi geolistrik dan geokomputasi mengidentifikasi dengan baik lokasi longsor adalah tipe luncuran ( fall) dan nendatan (slides). Begitupun korelasi antara geoteknik dan geokomputasi terdapat hubungan yang signifikan dimana antara zona bahaya longsor dengan faktor keamanan lereng. Hubungan ini mengisyaratkan bahwa semakin tinggi nilai skor bahaya longsor maka semakin rendah nilai faktor amannya, begitupun sebaliknya semakin rendah skor bahaya longsor maka semakin tinggi nilai faktor amannya. Dengan demikian, kejadian longsor di lokasi kajian terjadi karena dindikasikan dipengaruhi oleh faktor alami seperti berada disekitar jalur patahan dan retakan batuan yang merupakan kondisi lereng dengan tingkat kemiringan $>40 \%$, pelapukan batuan gunungapi Ambon, kondisi curah hujan yang cukup tinggi, dan sistem hidrologi pada lereng. Begitupun dengan faktor non-alami disebabkan oleh penggunaan lahan seperti deforisitasi lahan hutan yang tidak terkontrol dan penanaman jenis pohon tahunan kurang terpola.

Dari hasil kajian terpadu yang dihasilkan pasca longsor dalam kondisi tidak aman dan bisa terjadi longsor susulan jika dipicu oleh faktor luar. Untuk meminimalisir longsor susulan dengan menurunkan muka air tanah adalah menggunakan model tol air dengan memanfaatkan sungai-sungai kecil/besar yang terdapat di bawah lereng/tebing untuk dapat dialirkan air pada musim hujan. Apabila tidak terdapat sungai-sungai kecil di bawah lereng, dapat dibangun dam kecil untuk menampung air kemudian di pompa keluar dari dalam reservoir dan dialirkan melalui tebing-tebing curam. Sesungguhnya untuk membangun model tol air yang pemanfaatannya lebih efektif dan terintegrasi, maka perlu dilakukan kajian yang mendalam mengenai topografi dan vegetasi permukaan serta permukaan DAS disekitarnya, dan juga diintegrasikan dengan pendekatan teknologi 
geoforestri dan bioengineering sehingga masalah longsor dapat diminimalisir secara optimal.

\section{KESIMPULAN}

Lokasi bidang gelincir longsor dicirikan oleh anomali resistivitas dari struktur lapisan bawah permukaan yang rendah hingga sedang dan anomali ini memberikan citra resistivitas jenis tanah lempung dan lempung pasiran, sedangkan anomali geoteknik batuan berdasarkan index properties yang sedang memprediksi adanya tanah lempung dan lempung pasiran, dan dari anomali geokomputasi memperlihatkan anomali tidak stabil berdasarkan zona bahaya dalam memprediksi zona potensi gerakan longsor. Berdasarkan kompilasi ini, anomali-anomali saling berkorelasi dan tersebar di sekitar sebaran lokasi longsor. Oleh karena itu, daerah potensi longsor Negeri Lima ditentukan berada tetap di sekitar sebaran longsor dan sedikit melebar ke arah utara dan barat laut dengan jangkauan yang cukup luas.

Untuk meminimalisir longsor susulan adalah menggunakan model tol air dengan memanfaatkan sungai-sungai kecil/besar yang terdapat di bawah lereng/tebing untuk dapat dialirkan air pada musim hujan. Model tol air diintegrasikan dengan pendekatan teknologi geoforestri dan bioengineering sehingga masalah longsor dapat dikurangi secara optimal.

\section{DAFTAR PUSTAKA}

1 Sassa, K. \& Canuti, P. 2009. Landslides Disaster Risk Reduction. Springer-Verlag. Berlin Heidelberg.

2 Malamud, B.D., Turcotte, D.L., Guzzetti, F. \& Reichenbach, P. 2004. Landslide Inventories and Their Statistical Properties. Journal of Earth Surface Processes and Landforms, 29 (6), 687-711.

3 Bell, R., Petschko, H., Röhrs, M. \& Dix, A. 2012. Assessment of Landslide Age, Landslide Persistence and Human Impact Using Airborne Laser Scanning Digital Terrain Models. Geografiska Annaler: Series A Physical Geography, 94 (1), 135-156.

4 Varnes, D. J. \& IAEG. 1984. Commission on Landslides and other Mass-Movements: Landslide hazard zonation: a review of principles and practice. UNESCO Press. Paris.

5 Sassa, K. 2013. International Programme on Landslides. Springer-Verlag. Berlin Heidelberg.

6 Crozier, M.J. 2010. Landslide Geomorphology: An Argument for Recognition, With Examples from New Zealand. Geomorphology, 120 (1-2), 3-15.

7 Korup, O., Densmore, A.L. \& Schlunegger, F. 2010. The Role of Landslides in Mountain Range Evolution, Geomorphology, 120 (1-2), 77-90.

8 Petley, D. 2012. Global Patterns of Loss of Life from Landslides. Journal Geology, 40 (10), 927-930.

9 Bachri, S. \& Sheresta, R.P. 2010. Landslide hazard Assessment Using Analytic Hierarchy Processing (AHP) and Geographic Information System in Kaligesing Mountain Area of Central Java Province Indonesia. Journal of 5th Annual International Workshop \& Expo on Sumatra Tsunami Disaster \& Recovery, 107-112.

10 Groen, E.T. dan Jacobs, C. 2012. Risk Mapping Indonesia Sector Disaster Risk Reduction \& Emergency Aid. Cordaid

11 Souisa, M., Hendrajaya, L. \& Handayani, G. 2014. Investigasi Awal Mekanisme Tanah Longsor di Pulau Ambon, Provinsi Maluku. Proceedings Seminar of Basic Science VI, FMIPA Ambon, 1 (1), 23-32.

12 Souisa, M., Hendrajaya, L. \& Handayani, G. 2015. Determination of Landslide Slip Surface Using Geoelectrical Resistivity Method at Ambon City Moluccas Indonesia. Internasional Journal, IJTAE, 5 (7), $42-47$. 
13 Luna, R. \& Jadi, H. 2000. Determination of Dynamic Soil Properties Using Geophysical Methods. Proceedings of the First International Conference on the Application of Geophysical and NDT Methodologies to Transportation Facilities and Infrastructure, St. Louis, MO, 1-15.

14 Dobrescu, C., Calarasu, E. \& Stoica, M. 2011. Landslides Analysis Using Geological, Geotechnical, Geophysical Data from Experimental Measurement in Prahova Country. Urbanism, Architecture, Construction, 2 (4), 55-62.

15 Abidin, M.H.B.Z., Saad, R.B., Ahmad, F.B., Wijeyesekera, D.C. \& Baharuddin, M.F.B.T. 2012. Integral Analysis of Geoelectrical (Resistivity) and Geotechnical (Spt) Data in Slope Stability Assessment. Academic Journal of Science, 1 (2), 305-316.

16 Akinrinmade, A.O., Ogunsanwo, O. \& Ige, O.O. 2013. Geophysical and Geotechnical Investigation of River Ero, Ajuba, Southwestern Nigeria for Dam Development. International Journal of Science and Technology, 2 (7), 516-528.

17 Grandjean, G. 2009. From Geophysical Parameters to Soils Characteristics. FP7-DIGISOIL Project Deliverable 2.1.

18 Soralumb, S. 2010. Corporative of Geotechnical Approach for Landslide Susceptibility Mapping in Thailand. Geothechnique and Geosynthetics for Slopes. Chiangmai, Thailand, 1-8.

19 Anwar, A. 2012. Mapping Prone Areas of Landslide in Agricultural Land subdistrict of West Sinjai. Skripsi. Program Studi Keteknikan Pertanian Fakultas Pertanian Universitas Hasanuddin Makassar.

20 Souisa M., Hendrajaya L., \& Handayani, G. 2015. Landslide Dynamics and Determination Critical Condition Using of Resistivity Method in Desa Negeri Lima Ambon. Indonesian Journal of Physics, 26 (1), 1-4.

21 Tjokrosapoetro, S., Rusmana, E. \& Suharsono, 1994. Geologi Lembar Ambon, Maluku (Geological Map of the Ambon Sheet, Maluku), Lembar (Sheet) 2612-2613, Skala (Scale) 1:250.000. Direktorat Jenderal Geologi dan Sumberdaya Mineral, Pusat Penelitian dan Pengembangan Geologi, Republik Indonesia.

22 Sapulete, M.S., Sismanto, \& Souisa, M. 2012. Mapping of Lateritic Nickel Deposit Using Resistivity Method at Gunung Tinggi Talaga Piru, Western Seram Regency, Mollucas Province. Proceeding 1st Earth Science International Seminar Yogyakarta 29th November, 132-138.

23 Telford, M.W., Geldart, L.P., Sherrif, R.E. dan Keys, D.A. 2004. Applied Geophysics. Cambridge University Press, Cambridge New York, 556-557.

24 Kirsch, R. 2006. Groundwater Geophysics: A Tool for Hydrogeology. Springer Berlin Heidelberg, New York.

25 Brinkgreve, R.B.J. 2011. PLAXIS Professional 2D Version 8: Finite Element Code for Soil and Rock Analyses. A.A. Balkema Publishers, a member a Swets \& Zeitlinger Publishers, Netherlands.

26 Pattiselanno, S.R.R., Anwar, M.R. \& Hasyim, A.W. 2014. Handling Landslide Region watershed of Wai Ruhu. Jurnal Rekayasa Sipil, 8 (1), 17-29.

27 Abad, S.V.A.N.K., Mohamad, E.T., Jahanmirinezhad, H., Hajihassani, M. \& Namazi, E. 2011. Zonation of Landslide Hazards Based on Weights of Evidence Modeling Along Tehran-Chalos Road Path, Iran. Journal of EJGE, 16, 1083-1097.

28 Souisa M., Hendrajaya, L. \& Handayani, G. 2016. Landslide Hazard and Risk Assessment for Ambon City Using Landslide Inventory and Geographic Information System. Journal of Physics: Conference Series, 739, 1-11

29 Anonymous, 2012. The Regulation of the National Disaster Management Agency No. 02 of 2012 on General Guidelines for Disaster Risk Assessment. Jakarta, 11-26. 